\title{
Incidence of Multiple and Distinct Species of Caulimoviruses in Dahlia (Dahlia variabilis)
}

\author{
Sahar Eid and Keri L. Druffel \\ Department of Plant Pathology, Washington State University, 345 Johnson \\ Hall, P.O. Box 646430, Pullman, WA 99164
}

Dayle E. Saar
Department of Biological Sciences, Murray State University, Murray, KY
42071

Hanu R. Pappu ${ }^{1}$

Department of Plant Pathology, Washington State University, 345 Johnson Hall, P.O. Box 646430, Pullman, WA 99164

Additional index words. Dahlia mosaic virus, Caulimoviruses, virus incidence, Dahlia

\begin{abstract}
Dahlia mosaic is a serious disease affecting dahlias. In addition to the Dahlia mosaic virus (DMV) reported previously, we characterized two putative new caulimoviruses, tentatively designated as DMV-D10 and Dahlia common mosaic virus (DCMV), from dahlia. To better understand their relative incidence in dahlia, a total of 213 samples were collected during 2007 and 2008 from several varieties of cultivated dahlia (D. variabilis) in the United States. Samples were tested for the three caulimoviruses using virus-specific primers in a polymerase chain reaction. Amplicons were cloned and sequenced to confirm the infection of dahlia with these viruses. Results showed that DMV-D10 was the most prevalent (94\%) followed by DCMV $(48.5 \%)$ and DMV $(23 \%)$. Mixed infections were common and viruses were detected irrespective of symptom expression at the time of sampling. Two percent of the samples were not infected by any of the three tested caulimoviruses. Results suggest that caulimovirus infections are widespread in dahlia and highlight the need for testing and production of virus-free material to reduce their spread.
\end{abstract}

Dahlia is a high-value flower crop in the United States (Pappu et al., 2005) and several other countries in the world (Albouy, 1995; Brunt, 1971). The genus Dahlia, whose vernacular name is also "dahlia," is in the sunflower family, Asteraceae. Currently, 35 wild species are recognized (Saar and Sørensen, 2005) plus the cultivated forms, known as either $D$. pinnata or $D$. variabilis. There are many thousands of named cultivars of D. variabilis in the world (The International Register of Dahlia Names, 1969 et seq.).

Received for publication 6 Apr. 2009. Accepted for publication 26 May 2009.

Research was supported in part by the Samuel and Patricia Smith Endowment for Dahlia Virus Research created by the American Dahlia Society, USDA Northwest Nursery Crop Research Center, and the Washington State Commission for Pesticide Registration. S. Eid is supported in part by a graduate student research assistantship from the WSU-Agricultural Research Center. PPNS No. 0509, Department of Plant Pathology, College of Agricultural, Human and Natural Resource Sciences, Agricultural Research Center, Project No. WNPO 0545, Washington State University, Pullman, WA.

${ }^{1}$ To whom reprint requests should be addressed; e-mail hrp@wsu.edu.
There are more than a dozen viruses that infect dahlia (Albouy, 1995). All of these viruses are RNA viruses except one DNA virus, Dahlia mosaic caulimovirus (DMV). DMV is widely prevalent in cultivated dahlias and causes an economically important disease referred to as dahlia mosaic (Albouy, 1995; Brunt, 1971). Symptoms of dahlia mosaic disease include mosaic, vein clearing, vein-banding, leaf distortion, systemic chlorosis, and overall stunting of the plant (Pappu and Wyatt, 2003; Pappu et al., 2005). Symptoms vary depending on the cultivar, and cultivars with few or no symptoms are common. DMV is a member of the genus Caulimovirus family Caulimoviridae. In addition to DMV, which was characterized at the molecular level (Richins and Shepherd, 1983), recent studies have revealed the presence of at least two more caulimoviruses, tentatively referred to as DMV-D10 and Dahlia common mosaic virus (DCMV) (Nicolaisen, 2003; Pahalawatta et al., 2008a; Pappu et al., 2008). DMV-D10 shares limited sequence similarity with known caulimoviruses, including DMV, although the genome organization clearly suggests that it is a member of Caulimovirus (Pahalawatta et al., 2008a). DMVD10 was found to be widespread based on the surveys conducted in the United States and Europe (Pahalawatta et al., 2007; Pappu et al., 2005). Moreover, Pahalawatta et al. (2008b) reported that the genome of DMV-D10 is integrated into the dahlia genome and the virus exists as an endogenous plant pararetroviral sequence (EPRV). DCMV was found to be a distinct caulimovirus species based on sequence relationships with known caulimoviruses (Pappu et al., 2008).

Previous surveys for the caulimoviruses used partial sequences of DCMV (referred to as DMV-Holland in Pahalawatta et al., 2007) and results showed differences in relative incidence of the three caulimoviruses in the United States and The Netherlands. After the complete genome characterization of DCMV, it becomes evident that there are at least three distinct caulimoviruses that are associated with dahlia mosaic. The aim of this study was to determine the incidence of the three distinct caulimoviruses in dahlia.

\section{Materials and Methods}

Sample collection. A total of 213 dahlia (D. variabilis) samples were collected from display gardens in Washington State between June and Sept. 2007 and during Sept. 2008. A wide range of symptoms were noticed. These included mosaic, systemic chlorosis, leaf malformation, and stunting. Sampling was done randomly and irrespective of the presence of symptoms.

Total nucleic acid extraction. Total nucleic acids were extracted from dahlia samples using the modified Dellaporta procedure (Presting et al., 1995) as described in Pahalawatta et al. (2007).

Polymerase chain reaction amplification. Primer pairs specific to each of the three virus species were used (Table 1). The quality of the extracted DNA was verified by polymerase chain reaction (PCR) using a hostspecific primer pair designed based on a portion of the internal transcribed spacer regions of dahlia (GenBank \#AF165831.1). A 1:20 dilution of the total nucleic acid extract was used in PCR. Each $20 \mu \mathrm{L}$ PCR reaction contained $2 \mu \mathrm{L}$ of the total nucleic acid extract, $1 \times$ PCR buffer (20 mm Tris, $\mathrm{pH} 8.4$, and $500 \mathrm{~mm} \mathrm{KCl}$ ), $150 \mu \mathrm{M}$ dNTP mix, $2 \mathrm{~mm}$ $\mathrm{MgCl}_{2}$, and 0.6 pmole each of forward and reverse primers, $12.7 \mu \mathrm{L}$ sterile $\mathrm{H}_{2} \mathrm{O}$, and 0.1 $\mu \mathrm{L}$ Taq DNA polymerase. The amplification was performed in a DNA thermal cycler (BioRad, Hercules, CA) with the following parameters: 50 cycles at $94{ }^{\circ} \mathrm{C}$ for $30 \mathrm{~s}$, the required annealing temperature (Table 1) based on the primer pair used for $20 \mathrm{~s}$, and $72{ }^{\circ} \mathrm{C}$ extension step determined based on the size of the amplicon to be synthesized (at the rate of $1000 \mathrm{bp} / \mathrm{min}$ ) preceded by an initial incubation of $94{ }^{\circ} \mathrm{C}$ for $4 \mathrm{~min}$ and ended by a final incubation at $72{ }^{\circ} \mathrm{C}$ for $7 \mathrm{~min}$. PCR products $(7.5 \mu \mathrm{L})$ were analyzed by agarose gel electrophoresis $(1.2 \%)$ in $0.5 \times$ TAE (Trisacetate-EDTA) buffer.

Cloning and sequencing of the amplicons. At least one amplicon for each of the virus species was cloned into TOPO vector (Invitrogen, Carlsbad, CA). Recombinant plasmids were sequenced at the Washington State University sequencing core facility. 


\begin{tabular}{|c|c|c|c|c|c|}
\hline & Primer pairs ${ }^{2}$ & Sequence $\left(5^{\prime}-3^{\prime}\right)$ & $\begin{array}{l}\text { Annealing } \\
\text { temp }\end{array}$ & $\begin{array}{l}\text { Extension } \\
\text { time }\end{array}$ & $\begin{array}{l}\text { Expected } \\
\text { size (bp) }\end{array}$ \\
\hline \multirow[t]{4}{*}{ DMV-D10 } & Orf 6 End/start & $\begin{array}{l}\text { ATGGAAGAAATTAAGGCGT } \\
\text { TTGTCTTCATCCATAAAGCAG }\end{array}$ & $60{ }^{\circ} \mathrm{C}$ & $1 \mathrm{~min} 30 \mathrm{~s}$ & 1,280 \\
\hline & Orf 6 1299-1300 & $\begin{array}{l}\text { CCAGGTGCAAGTCCGGAATTA } \\
\text { TAGGGCCAACTTCTGTCTCAT }\end{array}$ & $60{ }^{\circ} \mathrm{C}$ & $40 \mathrm{~s}$ & 513 \\
\hline & Orf 4 1926c/1431F & $\begin{array}{l}\text { TGCATAAAATGAGTTCTATC } \\
\text { TGAACTTGTTCATCATTATC }\end{array}$ & $53{ }^{\circ} \mathrm{C}$ & $30 \mathrm{~s}$ & 480 \\
\hline & Orf 1 416/1070 & $\begin{array}{l}\text { TTACCACTTCTAACAAAAGG } \\
\text { TCCATACATGTCTACTTTTTCG }\end{array}$ & $60{ }^{\circ} \mathrm{C}$ & $40 \mathrm{~s}$ & 600 \\
\hline DMV & Kapth F/R & $\begin{array}{l}\text { ATGAGTAATGCTTCAGCAA } \\
\text { TGACCATGGCTTCTAACTGT }\end{array}$ & $56{ }^{\circ} \mathrm{C}$ & $30 \mathrm{~s}$ & 504 \\
\hline DCMV & Den CP F/R & $\begin{array}{l}\text { GGATCCTCATTCTGAGTCTTCGTCTTC } \\
\text { CATATGGCCACCCAAATGACC }\end{array}$ & $59^{\circ} \mathrm{C}$ & $50 \mathrm{~s}$ & 1,517 \\
\hline
\end{tabular}

${ }^{2}$ Primer sequences for DCMV and DMV-D10 were from Pahalawatta et al. (2007, 2008b).

DMV- and internal transcribed spacer-specific primers were designed from GenBank accessions \#AY291586 and AF165831, respectively.

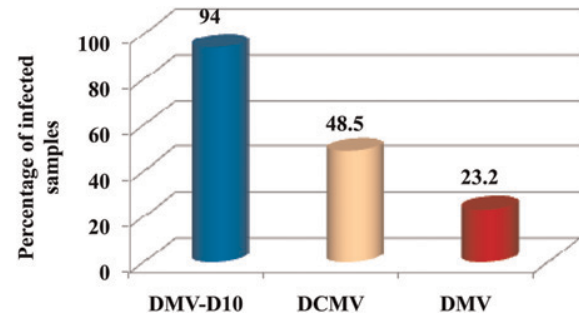

Fig. 1. Percent incidence of Dahlia mosaic virus (DMV), DMV-D10, and Dahlia common mosaic virus (DCMV) in cultivated dahlia. Virus-specific primers were used in a polymerase chain reaction assay. A total of 193 samples were tested.

Sequences were compared with the genomic sequences of the three viruses to confirm the identity of the amplicons.

\section{Results and Discussion}

Of the 193 symptomatic and asymptomatic dahlia samples collected from a dahlia display garden in 2007, DMV-D10 was found in $94 \%$ (Fig. 1) of the samples. Specific amplicons of expected size were obtained from each of the primer pair used and the sequence results verified their identity. DCMV was the second most frequent virus, after DMV-D10, found during the survey (Fig. 2). Mixed infections were common. The frequency of incidence of DMV alone and associated with other viruses was low compared with DMV-D10 and DCMV and it ranged between $17 \%$ and $26 \%$ (Fig. 2). The occurrence of mixed infections containing all three caulimoviruses, DMV-D10, DMV, and DCMV, ranged from $8.82 \%$ to $15.63 \%$ in 2007 (Fig. 2). The results of the 20 samples collected in Sept. 2008 also showed the relatively higher incidence of DMV-D10 and DCMV compared with that of DMV (Fig. 2).

Symptoms associated with virus infection included mosaic, mottling, vein chlorosis, and necrosis and in some plants resulted in stunting. There was no noticeable correlation between the detection of the virus and the symptom expression as $38 \%$ to $41 \%$ of
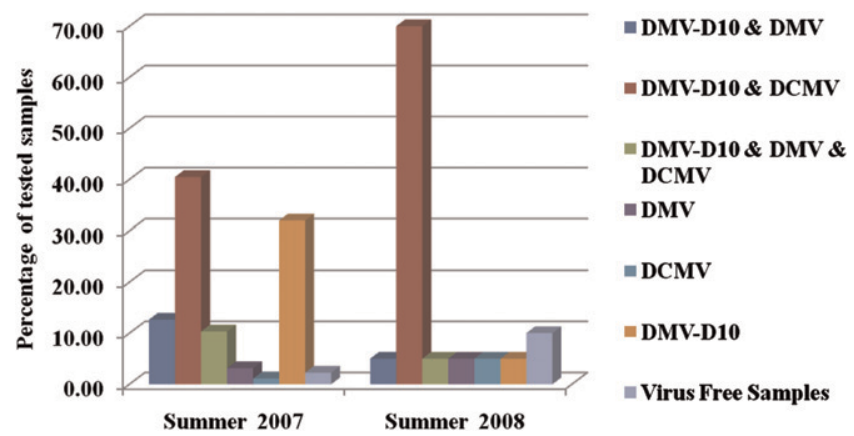

Fig. 2. Relative incidence (percent) of Dahlia mosaic virus (DMV), DMV-D10, and Dahlia common mosaic virus (DCMV) in 213 samples of cultivated dahlias tested in 2007 and 2008.

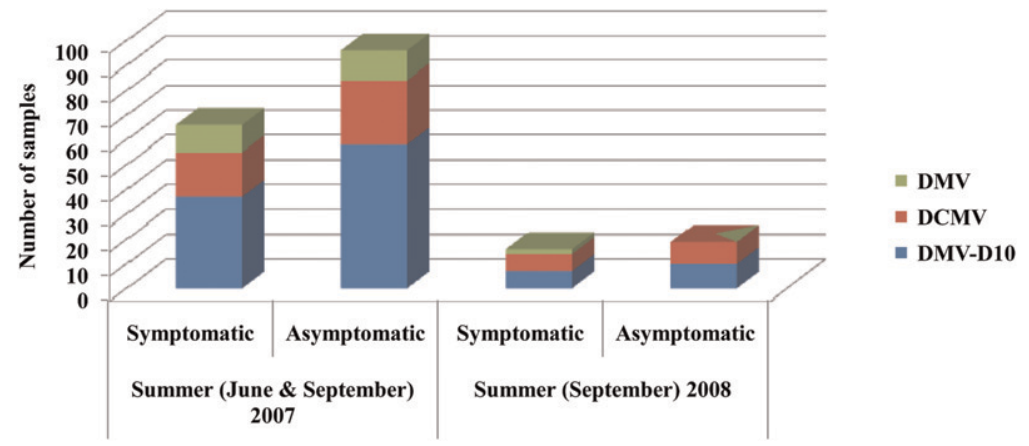

Fig. 3. Number of symptomatic (mosaic, mottling, vein chlorosis and necrosis, with stunting) and asymptomatic plants collected in June and Sept. 2007 and Sept. 2008.

DMV-D10-infected samples and $40 \%$ to $44 \%$ of DCMV-infected samples showed symptoms (Fig. 3). However, plants were frequently infected with more than one virus, and the majority of samples were asymptomatic but were found to be positive by PCR. DMV-D10 incidence was higher (greater than $50 \%$ ) in asymptomatic samples compared with DCMV and DMV (Fig. 3).

Results of this study showed the widespread occurrence of DMV-D10 in cultivated dahlias. Additionally, testing showed that DCMV was more prevalent than DMV, and mixed infections were common. This is supported by earlier studies (Pahalawatta et al., 2008a; Pappu et al., 2005). Infection of dahlia plants by DMV-D10 was often asymptomatic (greater than $50 \%$ of tested samples) but sometimes resulted in showing symptoms (mentioned previously). The high incidence of DMV-D10 could be because this virus was shown to exist as an EPRV (endogenous pararetroviral sequence) (Pahalawatta et al., 2008b) and for this reason, different primer sets to detect DMV-D10 were used. It was reported that EPRVs are not always neutral and they contribute to pathogenicity as shown in the case of Tobacco vein clearing virus (TVCV) and Petunia vein clearing virus (PVCV) (Harper et al., 1999; Lockhart et al., 2000; Ndowora et al., 1999; Richert-Poggeler et al., 2003).

The other two caulimoviruses, DCMV and DMV, do not appear to be integrated into 
the dahlia genome and instead they seem to exist as episomal elements typical of other known species in the genus Caulimovirus (Pahalawatta et al., 2008b). DCMV was the second most prevalent caulimovirus after DMV-D10 followed by DMV in incidence with $48.5 \%$ and $23 \%$, respectively (Fig. 1). In a previous survey by Pahalawatta et al. (2007) of dahlias in the United States and The Netherlands, DCMV and DMV infections were $31.9 \%$ and $21.8 \%$, respectively. Mixed infections were found to be common, whereas the frequency of incidence of DMV and DMVD10 (9.38\%) together was low compared with DMV-D10 and DCMV (43.75\%) (Fig. 2), and $15.6 \%$ of the samples had all three viruses.

The results from testing the cultivated dahlias highlight the importance of screening dahlia propagative material for these three viruses before using them in vegetative propagation, especially that presence of symptoms is not a criterion for virus infection diagnosis. At present, PCR-based detection assays are the most reliable methods for detecting viruses associated with dahlia mosaic. Reducing the spread and impact of these viruses in dahlia requires production of virus-free stock, and virus interception and elimination tactics should take into account the diversity of caulimoviruses extant in dahlia.

\section{Literature Cited}

Albouy, J. 1995. Dahlia, p. 265-273. In: Lobenstein, G., R.H. Lawson, and A.A. Brunt (eds.). Virus and virus-like diseases of bulb and flower crops. John Wiley and Sons, Chichester, NY.

Brunt, A.A. 1971. Some hosts and properties of dahlia mosaic virus. Ann. Appl. Biol. 67:357368.

Harper, G., J.O. Osuji, J.S. Heslop-Harrison, and R. Hull. 1999. Integration of Banana streak Badnavirus into the Musa genome: Molecular and cytogenetic evidence. Virology 255:207-213.

Lockhart, B.E., J. Menke, G. Dahal, and N.E Olszewski. 2000. Characterization and genomic analysis of tobacco vein clearing virus, a plant pararetrovirus that is transmitted vertically and related to sequences integrated in the host genome. J. Gen. Virol. 81:1579-1585.

Ndowora, T., G. Dahal, D. Lafleur, G. Harper, R. Hull, N.E. Olszewski, and B. Lockhart. 1999. Evidence that badnavirus infection in Musa can originate from integrated pararetroviral sequences. Virology 255:214-220.

Nicolaisen, M. 2003. Partial molecular characterization of Dahlia mosaic virus and its detection by PCR. Plant Dis. 87:945-948.

Pahalawatta, V., K.L. Druffel, S.D. Wyatt, K.C. Eastwell, and H.R. Pappu. 2008a. Genome structure and organization of a novel and distinct species of genus Caulimovirus (family Caulimoviridae) associated with dahlia mosaic. Arch. Virol. 153:733-738.

Pahalawatta, V., K.L. Druffel, and H.R. Pappu. 2008b. A new and distinct species in the genus Caulimovirus exists as an endogenous plant pararetroviral sequence in its host, Dahlia variabilis. Virology 376:253-257.

Pahalawatta, V., R. Miglino, K.L. Druffel, A. Jodlowska, A.R. Van Schadewijk, and H.R. Pappu. 2007. Incidence and relative prevalence of distinct caulimoviruses (genus Caulimovirus, family Caulimoviridae) associated with dahlia mosaic in Dahlia variabilis. Plant Dis. 91:1194 1197.

Pappu, H.R., K.L. Druffel, R. Miglino, and A.R. Van Schadewijk. 2008. Nucleotide sequence and genome organization of a new and distinct caulimovirus associated with dahlia mosaic. Arch. Virol. 153:2145-2148.

Pappu, H.R. and S.D. Wyatt. 2003. Dahlia mosaic virus. A description of symptoms on dahlia. APSnet Image of the Week. Mar. 2009. <http:// apsnet.org/online/archive/2003/IW000032.asp>.

Pappu, H.R., S.D. Wyatt, and K.L. Druffel. 2005. Dahlia mosaic virus: Molecular detection and distribution in dahlia in the United States. HortScience 40:697-699.

Presting, G.G., O.P. Smith, and C.R. Brown. 1995. Resistance to potato leaf roll virus in potato plants transformed with the coat protein gene or with vector control constructs. Phytopathology $85: 436-442$.

Richert-Poggeler, K.R., F. Noreen, T. Schwarzacher, G. Harper, and T. Hohn. 2003. Induction of infectious petunia vein clearing (pararetro) virus from endogenous provirus in petunia. European Molecular Biology Organization Journal 22: 4836-4845.

Richins, R.D. and R.J. Shepherd. 1983. Physical maps of the genome of Dahlia mosaic virus and Mirabilis mosaic virus-Two members of the Caulimovirus group. Virology 124: 208-214.

Saar, D.E. and P.D. Sørensen. 2005. Dahlia sublignosa: A species in its own right. SIDA Contributions to Botany 21:2161-2167.

The International Register of Dahlia Names. (1969 et seq.). Ninetheenth Supplement. The Royal Horticultural Society, London, UK. 